\title{
Effect of Basti Chikitsa \& Marma Chikitsa in Vatashtheela (BPH) \& Mutrakrichchhra (UTI)
}

\author{
Dr. Shalini Patel ${ }^{1}$, Prof. (Dr.) Sunil Kumar Joshi ${ }^{2}$, Dr. Sanjay Gupta ${ }^{3}$, Dr. Prashant Srivastav ${ }^{4}$ \\ ${ }^{1}$ Goverment Medical Officer (Ay), MS(Ay). State Ayurvedic Dispensary \& Health Wellness Centre, Kathauda, Ballia U.P. \\ ${ }^{2}$ Honourable Vice Chancellor of Uttarakhand Ayurved University, Dehradun. \\ ${ }^{3}$ Associate Professor, P.G. Dept. of Panchakarma, Rishikul Campus, Uttarakhand Ayurved University, Haridwar. \\ ${ }^{4}$ MD Scholar, Kriya Sharir, Major S. D. Singh PG Ayurvedic Medical College, Farrukhabad, UP. \\ DOI: 10.29322/IJSRP.11.11.2021.p11902 \\ http://dx.doi.org/10.29322/IJSRP.11.11.2021.p11902
}

\begin{abstract}
Vatashtheela is defined as "a Chala, Unnata, Ashtheelavata Granthi is developed in the region between the Guda and Basti due to vitiation of Apana Vayu, is called Vatashtheela. On the other hand, the term Mutrakrichchhra mainly deals with Krichchhrata (dysuria) and Shool (pain). The Pratyatma Lakshana of Mutrakrichchhra is "Dukhen Mutra Pravrittih" means discomfort during micturition. Vatashtheela may be correlated closely to BPH (Benign Prostatic Hyperplasia) both surgical anomaly and symptoms wise, whereas, Mutrakrichchhra correlate with UTI (sp. Lower Urinary Tract Infections i.e. urethritis \& cystitis) only symptoms wise. For a healthy life, Good urination habit is important. BPH and Urinary Tract Infection (UTI) is a common distressing and occasionally life threating condition. So, there is a need of appropriate Ayurvedic treatment. In this present research work, Basti Chikitsa \& Marma Chikitsa has been evaluated for Vatashtheela and Mutrakrichchhra management. Total 15 patients were selected based on inclusion \& exclusion criteria. Per rectum Basti was given once daily and locally Marma Chikitsa was apply thrice daily. Assessment was done according to subjective $\&$ objective parameters. The observations showed that satisfactory positive result without any complications. On the basis of subjective and objective parameters result was observed and analysed statistically. It was found that Basti Chikitsa \& Marma Chikitsa showed Highly significant result. Moreover, this treatment modality was well accepted by all the patients and did not produce any adverse effect during treatment as well as follow up period.
\end{abstract}

Index Terms- Vatashtheela, Mutrakrichchhra, BPH, UTI, Basti Chikitsa, Marma Chikitsa.

\section{INTRODUCTION}

A yurveda, is the oldest healthcare system in the world which deals with the science of life and longevity. Multifarious and extensive description of the urinary conditions are found in ancient literatures, like Egyptian, Chinese and the Middle Eastern.

In "Atharva Veda" the earliest description of urinary system is mentioned, so Ayurveda is said to be Upaveda of Atharvaveda. The $1^{\text {st }}$ description of Mutrasanga (urinary retention) and their surgical management by probing urethra $\&$ direct puncturing of urinary bladder (Basti) with arrow (Shara) is available in Atharvaveda [Atharvaveda 1:3:7:9]. Whereas, in Uttara Kanda of
Valmiki Ramayana's references regarding obstruction to urine's passage are available [V.R.35/50-55]. The use of "Loha-Shalaka" in the treatment of Mutraghata, give us an account of knowledge of our ancestors. ${ }^{[1]}$

The concept of Mutravaha Srotasa (urinary system), Mutrotpatti (urine formation), Basti (urinary bladder), and Shukravaha Srotasa (reproductive system) are explained by the ancient authors in a concise way. Maharshi Sushruta also describes the Marma in detail in a separate chapter of Sharira Sthana and has mentioned the importance of Marma as "Marmas cover half of the subject matter in the scope of Shalya Tantra (surgery)".[2]

Among various Mutraroga, Vatashtheela (Benign Prostatic Hyperplasia) and Mutrakrichchhra (Urinary Tract Infection) is the most common disorder of urinary tract, suffering the mankind very frequently. Acharya Dalhana, Chakrapani and Vijayarakshit have demarcated the difference between Mutrakrichchhra and Vatashtheela (a type of Mutraghata), as the symptom complex of both seems to be overlapping each other. This difference is grounded on the intensity of "Vibandha" or "Avarodha" (obstruction) which is more visible in Vatashtheela. Hence, it may be considered that the Vatashtheela is an Obstructive Uropathy, developed due to mechanical obstruction or functional disturbances. Acharya Vagabhatt has classically divided the Rogas of Mutra into two categories viz, Mutra Atipravrittija and Mutra Apravrittija Rogas. ${ }^{[3]}$

Acharya Sushruta defined Vatashtheela as "due to vitiation of Apana Vayu a Chala, Unnata, Ashtheelavata Granthi is developed in the region between the Guda and Basti, is called Vatashtheela". ${ }^{[4]}$

The Pratyatma Lakshana of Mutrakrichchhra is "Mutrasya krichchhren mahataa Dukhen pravrittih" ${ }^{[5]}$ means discomfort during micturition. UTI may be defined as "a condition in which bacteria enter, persist and multiply within the urinary trac". Sushruta has mentioned that Pratiloma Gati of Vata or Kupita Vayu is responsible for various Mutra Dosha ${ }^{[6]}$ or Basti Roga. ${ }^{[7]}$ Vatashtheela is one of the types of Mutraghata that reveal the symptoms of incomplete voiding, hesitancy, dribbling, nocturia, retention of urine, incontinence of urine, etc. These are chiefly the features related to the Lower Urinary Tract Symptoms (LUTS) that can be correlated closely to BPH (Benign Prostatic Hyperplasia) both surgical anomaly and symptoms wise. 
Acharya Sushruta classified diseases into two groups - one which are cured by surgical procedure (Shastra Saadhya) and the second ones which are cured by the use of therapies like Snehaadi. But having classified this way they are not exclusive of each other that means in Shastra Saadhya diseases we can use the therapies like Snehaadi whereas in Snehaadi Saadhya diseases we cannot use Shastra karma (surgical procedures) ${ }^{[8]}$.

According to Ayurvedic lexicons, Vata is the root cause of all the varieties of Mutraghata (including Vatashtheela) and Mutrakrichchhra. Basti mentioned in Ayurvedic classics, which is the treatment of choice in Vata pre-dominant diseases. Therefore, Basti Chikitsa covers "Half of the treatment of all the diseases" and Basti has been defined by Acharya Charaka as "Chikitsaardhamiti" [9].

As per the Samprapti of Vatashtheela and Mutrakrichchhra, there is deranged function of Vata Dosha, esp. Apana Vayu with the vitiation of other dosha. Therefore, the line of treatment is instituted as Vatahara, Mutrala, Bastishodhaka, Shothahara, Krimighna, and Lekhana, etc. to achieve the goal of desired treatment. Therefore, in this research work Basti Chikitsa and Marma Chikitsa are elected for the treatment of Vatashtheela \& Mutrakrichchhra.

\section{MATERIAL AND METHODS}

\section{AIMS \& OBJECTIVES :}

- To evaluate the efficacy of Basti Chikitsa ( Narayana Taila + Dashamula Kwatha) \& Marma Chikitsa in the management of Vatashtheela (BPH) \& Mutrakrichchhra (UTI).

- To find out any adverse effect of the treatment (drug), if any, during the therapy and follow up.

\section{SELECTION OF PATIENTS :}

In the present study total 15 patients diagnosed as suffering with either signs and symptoms of Vatashtheela (BPH) or Mutrakrichchhra (UTI) or both which were fulfilling the clinical criteria of diagnosis were randomly selected and registered irrespective of their gender, religion, occupation, education, etc. from Shalya OPD (No.7) \& Marma OPD (No.18) and Shalya IPD of P.G. Department of Shalya Tantra, Rishikul Campus \& Hospital, Uttarakhand Ayurved University, Haridwar (U.K.) India. A Specially Designed Research Proforma was prepared for this study and informed written consent of the patient was taken before starting the treatment. After the culmination of research, findings were analysed, observation $\&$ results were summarized.

\section{SAMPLING METHODE:}

A total number of 15 patients with signs and symptoms of Vatashtheela (BPH) and Mutrakrichchhra (UTI) were enrolled.

\section{INCLUSION CRITERIA:}

$>$ Age - Above 20 years.

$>$ Sex - Either sex, males for Vatashtheela.

$>$ Patients with clinical signs \& symptoms of Vatashtheela \& Mutrakrichchhra.

\section{EXCLUSION CRITERIA:}

$>$ Age below 20 yrs.

$>$ Patient with acute retention.

$>$ Malignant condition of Urogenital system.

$>$ Patient associated with other systemic disorders like Diabetes mellitus, Renal failure, Malignancy etc.

$>$ Patient not willing to undergo trial.

\section{METHOD OF RESEARCH}

Table No. I: Study Design:

\begin{tabular}{|c|c|c|c|c|c|}
\hline $\begin{array}{l}\text { No. of } \\
\text { Patients }\end{array}$ & Formulation & Dose & Route & Time & Duration \\
\hline \multirow[t]{2}{*}{15} & $\begin{array}{l}\text { Narayana } \\
\text { Taila+ } \\
\text { Dashamula } \\
\text { Kwatha }\end{array}$ & $\begin{array}{l}\text { Kwatha } 200 \mathrm{ml} / 60 \mathrm{ml} \\
\text { alternate day }+ \\
\text { Taila- } 20 \mathrm{ml} \text { per day }\end{array}$ & $\begin{array}{l}\text { Basti per } \\
\text { rectum }\end{array}$ & $\begin{array}{l}\text { In morning } \\
\text { hours }\end{array}$ & $\begin{array}{l}\text { For } 21 \\
\text { days }\end{array}$ \\
\hline & $\begin{array}{l}\text { Marma } \\
\text { Chikitsa }\end{array}$ & 15-18 Times/sitting & $\begin{array}{l}\text { Locally } \\
\text { (Indrabasti } \\
\text { Marma) }\end{array}$ & $\begin{array}{l}\text { In morning, } \\
\text { Afternoon \& } \\
\text { evening (3sitting of } \\
\text { Marma } \\
\text { Point) }\end{array}$ & $\begin{array}{l}\text { For } 21 \\
\text { days }\end{array}$ \\
\hline
\end{tabular}

\section{CRITERIA FOR DIAGNOSIS:}


Diagnosis was made on the basis of history, clinical signs \& symptoms of Vatashtheela (BPH) \& Mutrakrichchhra (UTI), examinations (general, systemic \& per rectal) and investigations.

\section{INVESTIGATIONS:}

1. Blood Examination: -

- Hb, T.L.C., D.L.C., E.S.R. Blood sugar (RBS, FBS, PP), S/Bilirubin, H.I.V, HbSAg to assess the general condition of patients.

- Blood urea and Serum creatinine to assess the functional status of urinary system.

- Serum acid phosphates, Serum alkaline phosphates and Serum prostate specific antigen (PSA) to exclude the possibility of carcinomatic conditions of prostate.

2. Urine examination.

4. Ultrasonography (USG) of whole abdomen to see the enlargement of prostate (to know size/volume/weight/post voided residual urine).

5. Urodynamics Evaluation by Uroflowmeter.

\section{PREPARATION OF TRIAL DRUGS:}

The trial drug Narayana Taila was prepared in Hans

Herbals Pvt. Ltd., Sidcul, Haridwar, UK under our supervision as per "Sneha Paka Kalpana" and Dashamula Kwatha was selfprepared daily as per the "Kwatha Kalpana" mentioned in classical texts.

Storage of Narayana Taila: The prepared Narayana Taila was filtered and preserved in airtight glass bottles.

\section{PROCEDURE OF BASTI CHIKITSA}

\section{POORVA KARMA:}

- The treatment with Basti procedure was explained to all the patients and a written informed consent was taken before starting the procedure.

- Patient was advised to go through the natural urges in the morning and to take a light Breakfast before Basti in the morning hours.

- Basti materials such as prepared Narayana Taila, Dashamula Kwatha, sterilized Rubber catheter \& Syringe (50/60cc), Gloves \& Gauze pieces etc. were kept ready before the application, then after patient had been asked to lie down on the table in left lateral position.

\section{PRADHANA KARMA:}

\section{Position -}

- In the classics, the position that must be followed is left lateral. Charaka has given explanation that Grahani and Guda are coming in the same direction. Therefore, one must follow the same position. ${ }^{[10]}$

- Logical thinking says that only in the left lateral position due to the gravitation the drugs may inter into the colon. In the medial side, the middle rectal valve is there which controls the sphincter continence which may get injured when the enema is given in the right lateral position.

- Left lateral position (i.e. with extended left lower limb, flexed right knee \& hip towards chest, on a comfortable table or bed. Perianal area was exposed.

\section{Procedure $^{[11]}$}

- First of all, Dashamula Kwatha was prepared as per Kwatha Kalpana Vidhi. After that, 20ml Narayana Taila (every day) and $200 \mathrm{ml} / 60 \mathrm{ml}$ (in alternate day ie. $200 \mathrm{ml}$ in first day, $60 \mathrm{ml}$ in second day, $200 \mathrm{ml}$ in third day and so on ...) lukewarm Dashamula Kwatha was taken in a bowl/container and mixed well to form a colloidal mixture, now with the help of 50/60 $\mathrm{ml}$ sterile syringe, the nozzle of which was connected with plain rubber catheter no. 8 .

- Now, the tip of the rubber catheter was lubricated by oil. Gently the tip of the rubber tube was introduced into the anal orifice for about four Angula Pramana $(10 \mathrm{cms})$. Patient was asked to be in relaxed state and then slowly medicament was pushed into the rectum by avoiding entry of air in a slow steady manner.

- Then slowly the catheter was withdrawn with little quantity of medicament remaining inside the syringe. Then patient was advised to lie down in supine position, keeping pillow below buttock, and a gentle tap given over the buttocks. Further the patient was instructed to lie down in supine position for a while.

\section{PASCHATA KARMA:}

- After given Basti, the patient was instructed to lie down in the left lateral position or in prone position for 10-30 minutes and to hold the Basti material as possible. As the patient gets urge for defecation, patient could pass the stool.

- During the course of treatment patient was advised to have Laghu \& Ushna Ahara on the same day evening and to avoid Sheet (to cold), Vidaahi (causing burning sensation), Vishtambhi (slow movement in G.I. tract), Ruksha (too dry \& causes aggravation of Vata).

\section{PROCEDURE OF MARMA CHIKITSA [12]}

Marma Chikitsa (therapy) is based on the wisdom of ancient Vedic Science and has been formulated in terms of most suitable technique for the present times.

\section{POORVA KARMA:}

- Patient was advised to take a light breakfast 1 to $1 \frac{1}{2}$ hour before coming to the hospital.

- Identification \& marking of the Indrabasti Marmas of upper extremity was done individually.

- Patients was advised to take deep breath at least 5-10 times before starting the, Marma therapy, to improve the flow of Prana Vayu. Due to which there is complete relaxation of musculature \& it is easy to perform, Marma therapy.

\section{PRADHANA KARMA:}

Posture - Sitting position on chair/stool or lying in supine position on the bed/table. For Self Marma therapy sitting position is most convenient. Therefore, was advised to patients.

\section{Procedure -}

- In sitting or lying in supine position keep the neck \& spine of the patients in straight line without stiffness or tilting towards any direction.

- After adopting the proper posture tell the patient, to close their eyes gently \& exhale forcefully, then inhale deeply for 5-10 times in rhythmic pattern. 
- Tell the patient to relax the whole-body musculature \& mind to remove physical \& mental tension and concentrate their mind on Indrabasti Marma point.

- Now start the pressing of Indrabasti Marma 15-18 times and each time should be equivalent to $0.8 \mathrm{sec}$ (i.e. one cardiac cycle) of each upper extremity with thumb, from right side of the body in male (and left side of the body in female).

- Patient was advised to take light meal after 1 to $1 \frac{1 / 2}{2}$ hour after this therapy.

\section{PASCHATA KARMA:}

Patients were advised to perform 2 sitting of "Self- Marma therapy" at their home. In Self- Marma therapy, patients were advised to press their own Indrabasti Marma point of each upper extremity with their own thumb of opposite hand, 15-18 times per sitting and each time should be equal to $0.8 \mathrm{sec}$. They were advised to perform Self-Marma therapy 1 to $1 \frac{1 / 2}{2}$ hour before or after meal.

\section{CRITERIA FOR GRADING \& ASSESSMENT}

\section{ON SUBJECTIVE PARAMETERS:}

Table No. II: Symptom Score According to IPSS (International Prostate Symptom Score) In BPH:

\begin{tabular}{|c|c|c|c|c|c|c|}
\hline S. No. & Symptoms & Grading & BT & D7 & D14 & D21 \\
\hline 1. & $\begin{array}{l}\text { Feeling of incomplete } \\
\text { bladder emptying }\end{array}$ & $\begin{array}{l}0=\text { Not at all } \\
1=\text { One or less than one } \\
2=\text { Less than half the time } \\
3=\text { About half time } \\
4=\text { More than half time } \\
5=\text { Almost always }\end{array}$ & & & & \\
\hline 2. & $\begin{array}{l}\text { Frequency of urination } \\
\text { (in daytime) }\end{array}$ & $\begin{array}{l}0=\text { Not at all } \\
1=\text { One or less than one } \\
2=\text { Less than half the time } \\
3=\text { About half time } \\
4=\text { More than half time } \\
5=\text { Almost always }\end{array}$ & & & & \\
\hline 3. & $\begin{array}{l}\text { Intermittency of urine } \\
\text { stream }\end{array}$ & $\begin{array}{l}0=\text { Not at all } \\
1=\text { One or less than one } \\
2=\text { Less than half the time } \\
3=\text { About half time } \\
4=\text { More than half time } \\
5=\text { Almost always }\end{array}$ & & & & \\
\hline 4. & Urgency of urination & $\begin{array}{l}0=\text { Not at all } \\
1=\text { One or less than one } \\
2=\text { Less than half the time } \\
3=\text { About half time } \\
4=\text { More than half time } \\
5=\text { Almost always }\end{array}$ & & & & \\
\hline 5. & Weak stream & $\begin{array}{l}0=\text { Not at all } \\
1=\text { One or less than one } \\
2=\text { Less than half the time } \\
3=\text { About half time } \\
4=\text { More than half time } \\
5=\text { Almost always }\end{array}$ & & & & \\
\hline 6. & Straining & $\begin{array}{l}0=\text { Not at all } \\
1=\text { One or less than one } \\
2=\text { Less than half the time } \\
3=\text { About half time } \\
4=\text { More than half time } \\
5=\text { Almost always }\end{array}$ & & & & \\
\hline 7. & $\begin{array}{l}\text { Nocturia (frequency of } \\
\text { urination in night) }\end{array}$ & $\begin{array}{l}0=\text { Not at all } \\
1=\text { One time } / \text { night } \\
2=\text { Two time } / \text { night }\end{array}$ & & & & \\
\hline
\end{tabular}




\begin{tabular}{|l|l|l|l|l|l|}
\hline & $\begin{array}{l}3=\text { Three time / night } \\
\text { 4 Four time / night } \\
\text { 5 = five time or more / night }\end{array}$ & & & \\
\hline TOTAL SCORE (Out of & $\begin{array}{l}1-7=\text { Mild } \\
8-19=\text { Moderate } \\
\text { 35) }\end{array}$ & & & & \\
& & & & & \\
\hline
\end{tabular}

Table No. III: Scoring Pattern of UTI:

\begin{tabular}{|c|c|c|c|c|c|c|}
\hline S. No. & Symptoms & Grading & BT & D7 & D14 & D21 \\
\hline 1. & Burning micturition & $\begin{array}{l}0=\text { Burning absent } \\
1=\text { Mild burning } \\
2=\text { Moderate burning } \\
3=\text { Severe burning }\end{array}$ & & & & \\
\hline 2. & $\begin{array}{l}\text { Painful micturition*ADL } \\
=\text { Activities of daily life }\end{array}$ & $\begin{array}{l}0=\text { No pain } \\
1=\text { Mild pain (nagging, annoying, } \\
\text { interfering little with ADLs) } \\
2=\text { Moderate pain (interferes } \\
\text { significantly with ADLs) } \\
3=\text { Severe pain (disabling, unable to } \\
\text { perform ADLs) }\end{array}$ & & & & \\
\hline 3. & $\begin{array}{l}\text { Frequency of } \\
\text { micturition }\end{array}$ & $\begin{array}{l}0=5-7 \text { times } \\
1=8-10 \text { times } \\
2=11-13 \text { times } \\
3=\text { More than } 13 \text { times }\end{array}$ & & & & \\
\hline 4. & Urgency & $\begin{array}{l}0=\text { Absent } \\
1=\text { Urgency but under control } \\
2=\text { Urgency difficult to control } \\
3=\text { Beyond control, even passes few } \\
\text { drops of urine }\end{array}$ & & & & \\
\hline
\end{tabular}

Table No. IV: Grading Based on Total Score of IPSS (Maximum Score 35):

\begin{tabular}{|c|c|c|}
\hline Grade & Symptom Score & Severity \\
\hline $\mathrm{G}_{0}$ & 00 & Not at all \\
\hline $\mathrm{G}_{1}$ & $1-7$ & Mild \\
\hline $\mathrm{G}_{2}$ & $8-19$ & Moderate \\
\hline $\mathrm{G}_{3}$ & $20-35$ & Severe \\
\hline
\end{tabular}

\section{ON OBJECTIVE PARAMETER:}

a). Uroflowmetry (Qmax -maximum flow rate):

1. Gr 0: $\mathrm{Qmax}=>15 \mathrm{ml} / \mathrm{sec}$

2. Gr 1: $\operatorname{Qmax}=13-15 \mathrm{ml} / \mathrm{sec}$

3. Gr 2: $\operatorname{Qmax}=10-12 \mathrm{ml} / \mathrm{sec}$

4. Gr 3: $\mathrm{Qmax}=7-9 \mathrm{ml} / \mathrm{sec}$

5. $\mathrm{Gr} 4: \mathrm{Qmax}=<7 \mathrm{ml} / \mathrm{sec}$

b). Ultrasonography (USG) whole Abd.: for weight/size/post voided residual urine .

ASSESSMENT: The overall effect of the therapy was assessed by the patients sign and symptoms according to subjective \& objective parameters. Assessment was done on every 7 days during 21 days of treatment period.

DURATION OF THERAPY: The duration of therapy was 21 Days.

FOLLOW UP: Cases were follow up at interval of 15 days, for a period of 2 months after completion of therapy.

\section{STATISTICAL ANALYSIS}

The Parameters of assessment was graded and statistically analysed. 
1. STATISTICAL TEST: All information which were based on subjective and objective parameters were gathered and statistical analysis was done in the form of Mean (X), Standard deviation (S.D.), Standard error (S.E.), and Friedman's test.

2. RESULT INTERPRETATION: The obtained results were interpreted as follow -

- If $\mathrm{p}>0.05$

- If $p=0.01$ to 0.05

- If $\mathrm{p} \leq 0.001$ (HS)

\section{PRESENTATION OF DATA:}

All collected clinical data was compiled and presented as -
- General observations.

- Effect of therapy on subjective and objective parameters.

- Overall effect of therapy.

\section{RESULT}

\section{EFFECT OF THERAPY ON SUBJECTIVE PARAMETERS VATASHTHEELA (BPH):}

In this present research work total 15 patients were enrolled, out of which all the patients had completed this clinical trial and results are statistically analysed.

Since observations are on ordinal scale (gradations), we have used "Friedman's test" to test efficacy at each follow up.

Table No. V: Effect of Therapy on Incomplete Bladder Emptying:

\begin{tabular}{|c|l|l|l|l|l|l|l|l|}
\hline $\begin{array}{l}\text { Incomplete } \\
\text { bladder } \\
\text { emptying }\end{array}$ & $\mathbf{N}$ & Mean & SD & & \% Effect & $\begin{array}{l}\text { Friedman's } \\
\text { Test }\end{array}$ & df & P value \\
\hline BT & 15 & 2.33 & 0.90 & 3.80 & 00.00 & 42.12 & 3.00 & 0.001 \\
\hline Day 7 & 15 & 1.53 & 0.64 & 2.63 & 34.29 & & & \\
\hline Day 14 & 15 & 1.47 & 0.52 & 2.57 & 37.14 & & & \\
\hline Day 21 & 15 & 0.20 & 0.41 & 1.00 & 91.43 & & & \\
\hline
\end{tabular}

From above Table we can observe that p-values is less than 0.05 . Hence, we conclude that effect observed is significant.

Table No.VI: Effect of Therapy on Frequency of Urination:

\begin{tabular}{|l|l|l|l|l|l|l|l|l|}
\hline $\begin{array}{l}\text { Frequency } \\
\text { of } \\
\text { Urination }\end{array}$ & $\mathbf{N}$ & Mean & SD & & \% Effect & $\begin{array}{l}\text { Friedman's } \\
\text { Test }\end{array}$ & df & P value \\
\hline BT & 15 & 2.53 & 0.74 & 3.93 & 00.00 & 43.74 & 3.00 & 0.000 \\
\hline Day 7 & 15 & 1.60 & 0.63 & 2.57 & 36.84 & & & \\
\hline Day 14 & 15 & 1.53 & 0.52 & 2.50 & 39.47 & & & \\
\hline Day 21 & 15 & 0.20 & 0.41 & 1.00 & 92.11 & & & \\
\hline
\end{tabular}

From above Table we can observe that p-values is less than 0.05 . Hence, we conclude that effect observed is significant.

Table No. VII: Effect of Therapy on Intermittency of Urine Stream:

\begin{tabular}{|l|l|l|l|l|l|l|l|l|}
\hline $\begin{array}{l}\text { Intermittency } \\
\text { of Urine } \\
\text { Stream }\end{array}$ & $\mathbf{N}$ & Mean & SD & & \% Effect & $\begin{array}{l}\text { Friedman's } \\
\text { Test }\end{array}$ & df & P value \\
\hline BT & 15 & 2.67 & 0.62 & 3.93 & 00.00 & 44.05 & 3.00 & 0.000 \\
\hline Day 7 & 15 & 1.73 & 0.46 & 2.53 & 35.00 & & & \\
\hline Day 14 & 15 & 1.73 & 0.46 & 2.53 & 35.00 & & & \\
\hline Day 21 & 15 & 0.27 & 0.46 & 1.00 & 90.00 & & & \\
\hline
\end{tabular}

From above Table we can observe that p-values is less than 0.05 . Hence, we conclude that effect observed is significant. 
Table No. VIII: Effect of Therapy on Urgency of Urination:

\begin{tabular}{|l|l|l|l|l|l|l|l|l|}
\hline $\begin{array}{l}\text { Urgency } \\
\text { of } \\
\text { Urination }\end{array}$ & $\mathbf{N}$ & Mean & SD & & \% Effect & $\begin{array}{l}\text { Friedman's } \\
\text { Test }\end{array}$ & df & P value \\
\hline BT & 15 & 2.73 & 0.70 & 4.00 & 00.00 & 42.62 & 3.00 & 0.001 \\
\hline Day 7 & 15 & 1.73 & 0.70 & 2.50 & 36.59 & & & \\
\hline Day 14 & 15 & 1.60 & 0.51 & 2.37 & 41.46 & & & \\
\hline Day 21 & 15 & 0.27 & 0.46 & 1.13 & 90.24 & & & \\
\hline
\end{tabular}

From above Table we can observe that p-values is less than 0.05 . Hence, we conclude that effect observed is significant.

Table No. IX: Effect of Therapy on Weak Stream:

\begin{tabular}{|l|l|l|l|l|l|l|l|l|}
\hline $\begin{array}{l}\text { Weak } \\
\text { Stream }\end{array}$ & $\mathbf{N}$ & Mean & SD & & \% Effect & $\begin{array}{l}\text { Friedman's } \\
\text { Test }\end{array}$ & df & P value \\
\hline BT & 15 & 2.53 & 0.83 & 3.87 & 00.00 & 42.88 & 3.00 & 0.001 \\
\hline Day 7 & 15 & 1.67 & 0.62 & 2.60 & 34.21 & & & \\
\hline Day 14 & 15 & 1.60 & 0.51 & 2.53 & 36.84 & & & \\
\hline Day 21 & 15 & 0.20 & 0.41 & 1.00 & 92.11 & & & \\
\hline
\end{tabular}

From above Table we can observe that p-values is less than 0.05 . Hence, we conclude that effect observed is significant.

Table No. X: Effect of Therapy on Straining:

\begin{tabular}{|l|l|l|l|l|l|l|l|l|}
\hline Straining & $\mathbf{N}$ & Mean & SD & & \% Effect & $\begin{array}{l}\text { Friedman's } \\
\text { Test }\end{array}$ & df & P value \\
\hline BT & 15 & 2.67 & 0.82 & 4.00 & 00.00 & 44.69 & 3.00 & 0.000 \\
\hline Day 7 & 15 & 1.67 & 0.82 & 2.53 & 37.50 & & & \\
\hline Day 14 & 15 & 1.60 & 0.63 & 2.47 & 40.00 & & & \\
\hline Day 21 & 15 & 0.27 & 0.46 & 1.00 & 90.00 & & & \\
\hline
\end{tabular}

From above Table we can observe that p-values is less than 0.05 . Hence, we conclude that effect observed is significant.

Table No. XI: Effect of Therapy on Nocturia:

\begin{tabular}{|l|l|l|l|l|l|l|l|l|}
\hline Nocturia & $\mathbf{N}$ & Mean & SD & & \% Effect & $\begin{array}{l}\text { Friedman's } \\
\text { Test }\end{array}$ & df & P value \\
\hline BT & 15 & 2.80 & 0.68 & 4.00 & 00.00 & 43.48 & 3.00 & 0.001 \\
\hline Day 7 & 15 & 1.80 & 0.68 & 2.53 & 35.71 & & & \\
\hline Day 14 & 15 & 1.67 & 0.49 & 2.40 & 40.48 & & & \\
\hline Day 21 & 15 & 0.20 & 0.41 & 1.07 & 92.86 & & & \\
\hline
\end{tabular}

From above Table we can observe that p-values is less than 0.05 . Hence, we conclude that effect observed is significant.

Table No. XII: Effect of Therapy on Total IPSS Score:

\begin{tabular}{|l|l|l|l|l|l|l|l|l|}
\hline $\begin{array}{l}\text { Total } \\
\text { IPSS } \\
\text { Score }\end{array}$ & $\mathbf{N}$ & Mean & SD & & \% Effect & $\begin{array}{l}\text { Friedman's } \\
\text { Test }\end{array}$ & df & P value \\
\hline BT & 15 & 18.27 & 1.87 & 4.00 & 00.00 & 45.000 & 3.00 & 0.001 \\
\hline Day 7 & 15 & 12.80 & 1.32 & 3.00 & 29.93 & & & \\
\hline Day 14 & 15 & 9.33 & 1.05 & 2.00 & 48.91 & & & \\
\hline Day 21 & 15 & 1.60 & 1.40 & 1.00 & 91.24 & & & \\
\hline
\end{tabular}


From above Table we can observe that p-values is less than 0.05 . Hence, we conclude that effect observed is significant. MUTRAKRICHCHHRA (UTI):

Table No. XIII: Effect of Therapy on Burning Micturition:

\begin{tabular}{|l|l|l|l|l|l|l|l|l|}
\hline $\begin{array}{l}\text { Burning } \\
\text { Micturition }\end{array}$ & N & Mean & SD & & \% Effect & $\begin{array}{l}\text { Friedman's } \\
\text { Test }\end{array}$ & df & P value \\
\hline BT & 15 & 1.93 & 0.80 & 3.67 & 00.00 & 39.82 & 3.00 & 0.001 \\
\hline Day 7 & 15 & 1.27 & 0.46 & 2.63 & 34.48 & & & \\
\hline Day 14 & 15 & 1.27 & 0.46 & 2.63 & 34.48 & & & \\
\hline Day 21 & 15 & 0.20 & 0.41 & 1.07 & 89.66 & & & \\
\hline
\end{tabular}

From above Table we can observe that p-values is less than 0.05 . Hence, we conclude that effect observed is significant.

Table No. XIV: Effect of Therapy on Painful Micturition:

\begin{tabular}{|l|l|l|l|l|l|l|l|l|}
\hline $\begin{array}{l}\text { Painful } \\
\text { Micturition }\end{array}$ & N & Mean & SD & & \% Effect & $\begin{array}{l}\text { Friedman's } \\
\text { Test }\end{array}$ & df & P value \\
\hline BT & 15 & 2.07 & 0.70 & 3.80 & 00.00 & 40.05 & 3.00 & 0.001 \\
\hline Day 7 & 15 & 1.27 & 0.46 & 2.53 & 38.71 & & & \\
\hline Day 14 & 15 & 1.27 & 0.46 & 2.53 & 38.71 & & & \\
\hline Day 21 & 15 & 0.20 & 0.41 & 1.13 & 90.32 & & & \\
\hline
\end{tabular}

From above Table we can observe that p-values is less than 0.05 . Hence, we conclude that effect observed is significant.

Table No. XV: Effect of Therapy on Frequency of Urination:

\begin{tabular}{|l|l|l|l|l|l|l|l|l|}
\hline $\begin{array}{l}\text { Frequency } \\
\text { of } \\
\text { Urination }\end{array}$ & $\mathbf{N}$ & Mean & SD & & \% Effect & $\begin{array}{l}\text { Friedman's } \\
\text { Test }\end{array}$ & df & P value \\
\hline BT & 15 & 1.80 & 0.41 & 3.80 & 00.00 & 39.00 & 3.00 & 0.000 \\
\hline Day 7 & 15 & 1.00 & 0.00 & 2.50 & 44.44 & & & \\
\hline Day 14 & 15 & 1.00 & 0.00 & 2.50 & 44.44 & & & \\
\hline Day 21 & 15 & 0.20 & 0.41 & 1.20 & 92.40 & & & \\
\hline
\end{tabular}

From above Table we can observe that p-values is less than 0.05 . Hence, we conclude that effect observed is significant.

Table No. XVI: Effect of Therapy on Urgency:

\begin{tabular}{|l|l|l|l|l|l|l|l|l|}
\hline Urgency & $\mathbf{N}$ & Mean & SD & & \% Effect & $\begin{array}{l}\text { Friedman's } \\
\text { Test }\end{array}$ & df & P value \\
\hline BT & 15 & 1.67 & 0.90 & 3.50 & 00.00 & 38.00 & 3.00 & 0.000 \\
\hline Day 7 & 15 & 1.13 & 0.52 & 2.70 & 32.00 & & & \\
\hline Day 14 & 15 & 1.13 & 0.52 & 2.70 & 32.00 & & & \\
\hline Day 21 & 15 & 0.20 & 0.41 & 1.10 & 92.30 & & & \\
\hline
\end{tabular}

From above Table we can observe that p-values is less than 0.05 . Hence, we conclude that effect observed is significant.

EFFECT OF THERAPY ON OBJECTIVE PARAMETERS:

Table No. XVII: Effect of Therapy on Uroflowmetry (Qmax):

\begin{tabular}{|l|l|l|l|l|l|l|l|l|}
\hline $\begin{array}{l}\text { Uroflowmetry } \\
\text { (Qmax) }\end{array}$ & $\mathbf{N}$ & Mean & SD & & \% Effect & $\begin{array}{l}\text { Friedman's } \\
\text { Test }\end{array}$ & df & P value \\
\hline BT & 15 & 2.67 & 0.49 & 4.00 & 00.00 & 44.05 & 3.00 & 0.000 \\
\hline Day 7 & 15 & 1.67 & 0.49 & 2.47 & 37.50 & & & \\
\hline
\end{tabular}




\begin{tabular}{|l|l|l|l|l|l|l|l|l|}
\hline Day 14 & 15 & 1.67 & 0.49 & 2.47 & 37.50 & & & \\
\hline Day 21 & 15 & 0.27 & 0.46 & 1.07 & 90.00 & & & \\
\hline
\end{tabular}

From above Table we can observe that p-values is less than 0.05 . Hence, we conclude that effect observed is significant.

* The Clinical trial of Basti Chikitsa \& Marma Chikitsa depicted Highly significant $(\mathrm{P} \leq 0.001)$ results, over all the mentioned symptoms / parameters.

\section{OVERALL EFFECT OF THERAPY}

Table No. XVIII: Overall Effect of Therapy:

\begin{tabular}{|l|c|c|}
\hline \multicolumn{1}{|c|}{ Effect of Therapy } & No. of Patients & \% Effect \\
\hline Complete Cured & 3 & $20 \%$ \\
\hline Marked Improvement & 10 & $66.66 \%$ \\
\hline Moderate Improvement & 1 & $6.66 \%$ \\
\hline Mild Improvement & 1 & $6.66 \%$ \\
\hline Unchanged & 0 & $0.00 \%$ \\
\hline
\end{tabular}

Further, it is observed that $3(20 \%)$ patients are completely cured, $10(66.66 \%)$ patients were revealed marked improvement, $1(6.66 \%)$ patient shown moderate improvement and $1(6.66 \%)$ patient shown mild improvement. Whereas, none of the patients belong to unchanged.

\section{DISCUSSION}

ON SUBJECTIVE PARAMETERS OF VATASHTHEELA (BPH):

\section{Effect on Incomplete Bladder Emptying:}

- The mean score of Incomplete bladders emptying was 3.80 (BT) which was reduced to 1.00 after therapy with $91.43 \%$ relief, and p-value is 0.001 which is statistically highly significant.

- As we known the Vata dosha is the prime cause for the disease Vatashtheela \& Basti Chikitsa along with Marma Chikitsa is the best treatment for Vatika disorders. So, from the above data it is clear that Basti Chikitsa \& Marma Chikitsa having the potency to pacify the vitiated Vata dosha and improved the bladder function by increasing its tone as well as reducing the size of the prostate.

- Ultimately the bladder outflow obstruction (BOO) was improved that's why improvement in incomplete bladder emptying was found.

\section{Effect on Frequency of Urination:}

- The mean score of Frequency of Urination was 3.93 (BT) which was reduced to 1.00 after therapy with $92.11 \%$ relief, and $\mathrm{p}$-value is $<0.001$ which is statistically highly significant.

- In BPH, hypertrophy of urinary bladder muscles occurs, and bladder tone affected that's why small amount of urine result as urge for urination that leads to frequency of urination. Since Basti Chikitsa \& Marma Chikitsa having the potency to pacify vitiated Vata (esp. Apana Vayu) as well as properties like Balya, Rasayana, Shothahara, Krimihara etc. of the formulated Basti drugs, are helpful to improve the function of Detrusor muscles of bladder and also reducing the prostate size. Therefore, encouraging effect of therapy was found on Frequency of Urination.

\section{Effect on Intermittency of Urine Stream:}

- The mean score of Intermittency of Urine Stream was 3.93 (BT) which was reduced to 1.00 after therapy with $90 \%$ relief, and p-value is $<0.001$ which is statistically highly significant.

- Intermittency shows that the weak bladder muscle which is unable to completely evacuate bladder in a single flow of urine due to stasis, inflammation, straining \& narrowing of the urethra.

- The effect of Basti Chikitsa \& Marma Chikitsa was seen on Vata dosha and the drugs used for Basti shows the properties such as Mutrala, Vata-shamaka, Bastishodhaka, Balya, Shothahara etc. which have the potency to provide strength to the Basti-Snayu and improve the function of bladder which lead to easy release of urine from Basti (bladder) without much effort

\section{Effect on Urgency of Urination:}

- The mean score of Urgency of Urination was 4.00 (BT) which was reduced to 1.13 after therapy with $90.24 \%$ relief, and pvalue is 0.001 which is statistically highly significant.

- As the internal sphincter function is deranged due to prostatic invasion into the bladder that leads to escape of small amount of urine into the prostatic urethra. So, there is an intense urge to excrete this urine immediately which is called urgency (Muhurmutrata). Since Basti Chikitsa \& Marma Chikitsa pacify Vata dosha and formulated drugs used in Basti having Shothahara property, that reduces the size of prostate, that's why there is no invasion of prostate into the bladder and decrease in this irritative symptoms will indicate relief in Vatashtheela (BPH).

\section{Effect on Weak Stream:}

- The mean score of Weak Stream was 3.87 (BT) which was reduced to 1.00 after therapy with $92.11 \%$ relief, and p-value is 0.001 which is statistically highly significant.

- At this time micturition is probably due to vesical introversion of the sensitive prostatic mucosa because of intravesical 
enlargement of the prostate due to its (prostate) enlargement, elongation of prostatic urethra occurs \& its calibre decreases. This alteration in urethra induces weak urine stream.

- So, reduction in this symptom reveal that Basti Chikitsa \& Marma Chikitsa having the potency to reduce the root causes of this symptom.

\section{Effect on Straining:}

- The mean score of Straining was 4.00 (BT) which was reduced to 1.00 after therapy with $90 \%$ relief, and p-value is $<0.001$ which is statistically highly significant.

- In the case of BPH, the resistance of the bladder outlet increases and the calibre of prostatic urethra decreases, so that patients with BPH strains during micturition will completely empty their bladder.

- $\quad$ The \% relief in this symptom show that the Basti Chikitsa \& Marma Chikitsa having the capability to decrease the bladder outlet resistance \& enhance the calibre of urethra by reducing the size of prostate gland and other causes which are responsible for this symptom.

\section{Effect on Nocturia:}

- The mean score of Nocturia was 4.00 (BT) which was reduced to 1.07 after therapy with $92.86 \%$ relief, and p-value is 0.001 which is statistically highly significant.

- The Vatashtheela (BPH) patients commonly complains the most irritative symptom nocturia due to predominance of Apana Vayu.

- Vata dosha continues to generate unnecessary contractions of bladder, in which some amount of urine \& Shotha already exists. Collectively, they generate nocturia. Basti Chikitsa \& Marma Chikitsa pacify Vata dosha \& Shotha of bladder. So, patient comes to ease.

\section{Effect on Total IPSS:}

- The mean score of Total IPSS was 4.00 (BT) which was reduced to 1.00 after therapy with $91.24 \%$ relief, and p-value is 0.001 which is statistically highly significant.

- $\quad$ Above data reflects that Basti Chikitsa \& Marma Chikitsa is very effective in reducing all the 7 LUTS which is included in IPSS.

\begin{tabular}{llr} 
ON SUBJECTIVE & PARAMETERS & OF \\
\hline MUTRAKRICHCHHRA (UTI): &
\end{tabular}

\section{Effect on Burning Micturition:}

- The mean score of Burning Micturition was 3.67 (BT) which was reduced to 1.07 after therapy with $89.66 \%$ relief, and pvalue is 0.001 which is statistically highly significant.

- This symptom is especially due to vitiation of Pitta dosha (as we know Pitta dosha is responsible for Daha i.e. burning) along with Vata dosha. Basti Chikitsa \& Marma Chikitsa pacify Vata and Pitta dosha and formulated drugs used for Basti Chikitsa having Mutrala, Bastishodhaka, Sheetal, Dahashamaka, Krimighna, Shothahara \& V-P Shamaka etc. properties which reduces the burning micturition effectively. So, patients got relief in this symptom of Mutrakrichchhra (UTI).

\section{Effect on Painful Micturition:}

- The mean score of Painful Micturition was 3.80 (BT) which was reduced to 1.13 after therapy with $90.32 \%$ relief, and pvalue is 0.001 which is statistically highly significant.

- As we know that existence of pain is due to Vata dosha and Prakrita Mutra is considered as Avedanam, which is achieved by Basti Chikitsa \& Marma Chikitsa because they are Vatahara \& Shulahara. The formulated drugs used in this therapy also removes Mutravaha Srotodushti from tissue level, pacifies Doshas, improves Agni, and brings Prakritavastha. It also has analgesic properties.

\section{Effect on Frequency of Micturition:}

- The mean score of Frequency of Micturition was 3.80 (BT) which was reduced to 1.20 after therapy with $92.40 \%$ relief, and p-value is $<0.001$ which is statistically highly significant.

- Since undue contractions of bladder is the Karma of Prakupita Vata that have been stopped by Basti Chikitsa \& Marma Chikitsa by its Vatahara property. Thus, the urinary bladder performs Samyaka Mutradharana and patients got relief from this symptom.

\section{Effect on urgency:}

- The mean score of Urgency was 3.50 (BT) which was reduced to 1.10 after therapy with $92.30 \%$ relief, and p-value is < 0.001 which is statistically highly significant.

- All the discomfort in LUTIs are due to Apakwa Mutra. Aama Mutrata and Shotha in urinary tract (i.e. Mutravaha Srotasa) leads to irritation of urinary bladder and urination. Therefore, there is an intense urge to excrete the Aama Mutra immediately that is termed as Urgency. Basti Chikitsa \& Marma Chikitsa pacify Vata dosha and by its Shothahara, Agnidipana, Bastishodhaka etc. properties of formulated drugs remove Aama Mutra and Shotha. That's why patients got relief in this symptom.

\section{DISCUSSION ON OBJECTIVE PARAMETERS:}

\section{Effect on Maximum Flow Rate (Qmax):}

- The mean score of Uroflowmetry (Qmax) was 4.00 (BT) which was reduced to 1.07 after therapy with $90 \%$ relief, and p-value is $<0.001$ which is statistically highly significant.

- Abnormal flow may be due to obstruction (of any aetiology) or detrusor hypo contractibility. Improvement in the Qmax by Basti Chikitsa \& Marma Chikitsa is obviously due to improved force of urine flow. This may be either due to increased bladder contractibility or decreased resistance to the flow of urine in the urethra.

\section{Effect on Prostate Size / Volume:}

All the 15 patients which were enrolled in this research work had completed this clinical trial, out of which we have got only 07 USG reports after completion of treatment. These reports show, outstanding response of therapy on the prostate size (volume) as well as on PVRU.

On the basis of these some USG reports, we have concluded that the treatment used in this study definitely reduces the Prostate size \& PVRU. But unfortunately, due to lack of USG reports of all 15 patients that completed this clinical trial, we can't show its result statistically. 


\section{CONCLUSION}

* The elected formulations for clinical trial i.e. Basti Chikitsa (Narayana Taila + Dashamula Kwatha) \& Marma Chikitsa had shown Tridosha Shamaka (esp. Vata-Kapha shamaka) action and Dipana, Pachana, Lekhana, Bastishodhaka, Balya, Shothahara, Mutrala, Krimighna, Rasayana, Ojovardhaka etc. properties and may be held responsible for breaking the Samprapti of Vatashtheela (BPH) and Mutrakrichchhra (UTI) as well as correction in imbalanced level of sex hormones and improving bladder functions by improving bladder muscle tone.

* There was no any untoward effect or adverse drug reaction (ADR) and recurrence recorded during treatment \& follow up among all the patients and it is clinically proven as a safe and effective therapy.

* In this research work, it was noted that the patients which was suffering from Vatashtheela (BPH) in their early age of life, showed better response to this therapy as compare to advanced aged patients.

Thus, it can conclude that Basti Chikitsa \& Marma Chikitsa can be used as a successful conservative treatment modality in the patients suffering from Vatashtheela (BPH) \& Mutrakrichchhra (UTI).

\section{REFERENCES}

[1] Atharvaveda. V -1 - 1/316-9.

[2] Sushruta Samhita, Sharirasthana, Pratyekamarmanirdesha shaariram, 6/33. Available from: http://niimh.nic.in/ebooks/esushruta (Accessed on 4 October 2020).

[3] Kaviraja Atridev Gupta, Ashtanga Sangraha, Reprint edition-2005, Chaukhambha Krishnadas Academy Publications, Varanasi 2005, chapter 9 verse 40 .

[4] Sushruta Samhita, Uttaratantra, Mutraghatapratishedhaadhyaya, 58/7. Available from: http://niimh.nic.in/ebooks/esushruta (Accessed on 4 October 2020).

[5] Sri Vijayarakshit and Sri Kantha Datta, on Madhava Nidana, Mutrakrichchhra Nidanam, 30/1-2. Available from; http://niimh.nic.in/ebooks/madhavanidana (Accessed on 3 October 2020).
[6] Sushruta Samhita, Nidanasthana, Ashmarinidanam, 3/27. Available from: http://niimh.nic.in/ebooks/esushruta (Accessed on 4 October 2020).

[7] Sushruta Samhita, Nidanasthana, Vatavyadhinidanam, 1/19. Available from: http://niimh.nic.in/ebooks/esushruta (Accessed on 4 October 2020).

[8] Sushruta Samhita, Sutrasthana, Vyadhisamuddesheeyaadhyaya, 24/3. Available from: http://niimh.nic.in/ebooks/esushruta (Accessed on 4 October 2020).

[9] Charaka Samhita, Siddhisthana, Kalpanasiddhi, 1/40. Available from: http://niimh.nic.in/ebooks/ecaraka (Accessed on 4 October 2020).

[10] Charaka Samhita, Siddhisthana, Bastisutriyasiddhi, 3/24. Available from: http://niimh.nic.in/ebooks/ecaraka (Accessed on 4 October 2020).

[11] Dr. Vasant C. Patil, Principles and Practice of Panchakarma, Reprint edition 2019, Chaukhambha Publications, New Delhi 2019. Chapter 13(Basti Karma) Pg no. 143-144.

[12] Dr. Sunil Kumar Joshi, Marma Science and Principles of Marma Therapy, Edition 1st, Vani Publications, Delhi August 2010.

\section{AUTHORS}

First Author - Dr. Shalini Patel, Goverment Medical Officer (Ay), MS(Ay). State Ayurvedic Dispensary \& Health Wellness Centre, Kathauda, Ballia U.P.

Second Author - Prof. (Dr.) Sunil Kumar Joshi, Honourable Vice Chancellor of Uttarakhand Ayurved University, Dehradun. Third Author - Dr. Sanjay Gupta, Associate Professor, P.G. Dept. of Panchakarma, Rishikul Campus, Uttarakhand Ayurved University, Haridwar.

Fourth Author - Dr. Prashant Srivastav, MD Scholar, Kriya Sharir, Major S. D. Singh PG Ayurvedic Medical College, Farrukhabad, UP.

Address for correspondence / Request for reprint:

Dr. Shalini Patel, N8/162, P-5-E, Rajendravihar Colony,Lane No 11, Newada, Sunderpur, Varanasi, 221005, India.

Phone: +91-8318135657, 9453222244, E-mail:

shalini22vns@gmail.com 